\title{
Aetiology of pleural plaques
}

\author{
V. ROUS and J. STUDENÝ \\ Departments of Tuberculosis and Pathology, State Hospital, Pelhřimov, Czechoslovakia
}

\begin{abstract}
Pleural plaques were found in $644(6.6 \%)$ of 9,760 photofluorograms taken in 1965 in a region of Pelhřimov district; the incidence was highest in the age group 66-70 years. The advanced age of those affected may be explained by the greater frequency of the causative agent in the past. The disorder was known in Pelhrimov district as early as 1930 ; it was then thought to be posttuberculous. The past history of the cases was uninformative; as a rule, the only common previous disease was pleurisy with effusion, occurring in $9.7 \%$. The general condition of those affected was excellent ; only $8 \%$ were aware of the fact that pleural lesions were present. The disorder was found mainly in farmers, familial incidence was common, and if two generations of one family suffered from the condition, the older generation was affected in $100 \%$.

Pleural plaques consist morphologically of limited areas of hyalinized collagenous connective tissue with calcium salt deposits. Tubercle bacilli could not be cultivated from the lesions. Mineralological analysis showed no evidence of silicates in the pleural plaques and a normal content in the lungs.

The aetiological factor responsible for the development of pleural plaques in Pelhrrimov district is not known, but asbestos cannot be implicated. The unknown noxious agent is carried to the pleura by the lymph and blood stream. Pleural plaques are an endemic disorder. The traditional view that lesions are post-tuberculous appears, in the region submitted to this study, to be a possible explanation.
\end{abstract}

Recently, a number of papers have been published on pleural plaques (PP), which are structures of calcific density located mainly in the costal and diaphragmatic pleura. Most of the writers on this subject have been in the field of industrial hygiene and have held the view that PP are due to the inhalation of asbestos dust, either in persons with occupational exposure to asbestos, or in persons not engaged in the manufacture or processing of asbestos who inhale a dust-polluted atmosphere. For this second mode of exposure, Kiviluoto (1965) has recommended the term 'endemic asbestosis' or 'pleural asbestosis' until more specific information becomes available.

A high incidence of PP in our district was noted by Hromek (1962) and Marsová (1964), but neither of these writers had any direct connection or access to the region under study. Their two papers were based chiefly on the interpretation of photofluorographic surveys, though Marsová also undertook the detailed clinical investigation of 15 cases. Both authors arrived at some conclusions which we were able to confirm or enlarge upon, but at others with which we cannot agree.

\section{GENERAL DATA ON REGION UNDER STUDY}

Our survey was made in the north-western portion of the district of Pelhrimov (Fig. 1). This is ax territory of $333 \mathrm{~km} .^{2}$ with a population in 1965 of $\frac{\sigma}{3}$ 16,178 . The density of the population is $48 / \mathrm{km} .^{2}$, one of the lowest in Czechoslovakia. Table IO shows that the proportion of persons aged 60 and over in this region is higher than in Czecho-을 slovakia as a whole.

The area is now mainly agricultural, but with some industry engaged in wood processing (saw- N mills and furniture) and food produation. The only engineering works was founded in 1950 in the small town of Pacov (3,500 inhabitants). The $\mathrm{W}$ number of persons employed in industry in 1961 was four times that in 1950 (Table II).

\section{METHODS AND RESULTS}

A photofluorographic survey of the population in $\frac{O}{\mathbb{D}}$ the region aged 15 years and over was carried out $\frac{\Omega}{\mathbb{}}$ in 1965. The units were equipped with Odelca $\stackrel{2}{2}$ cameras size $70 \times 70 \mathrm{~mm}$. and films of ORWO brand $70 \mathrm{~mm}$. A total of 12,245 persons were 


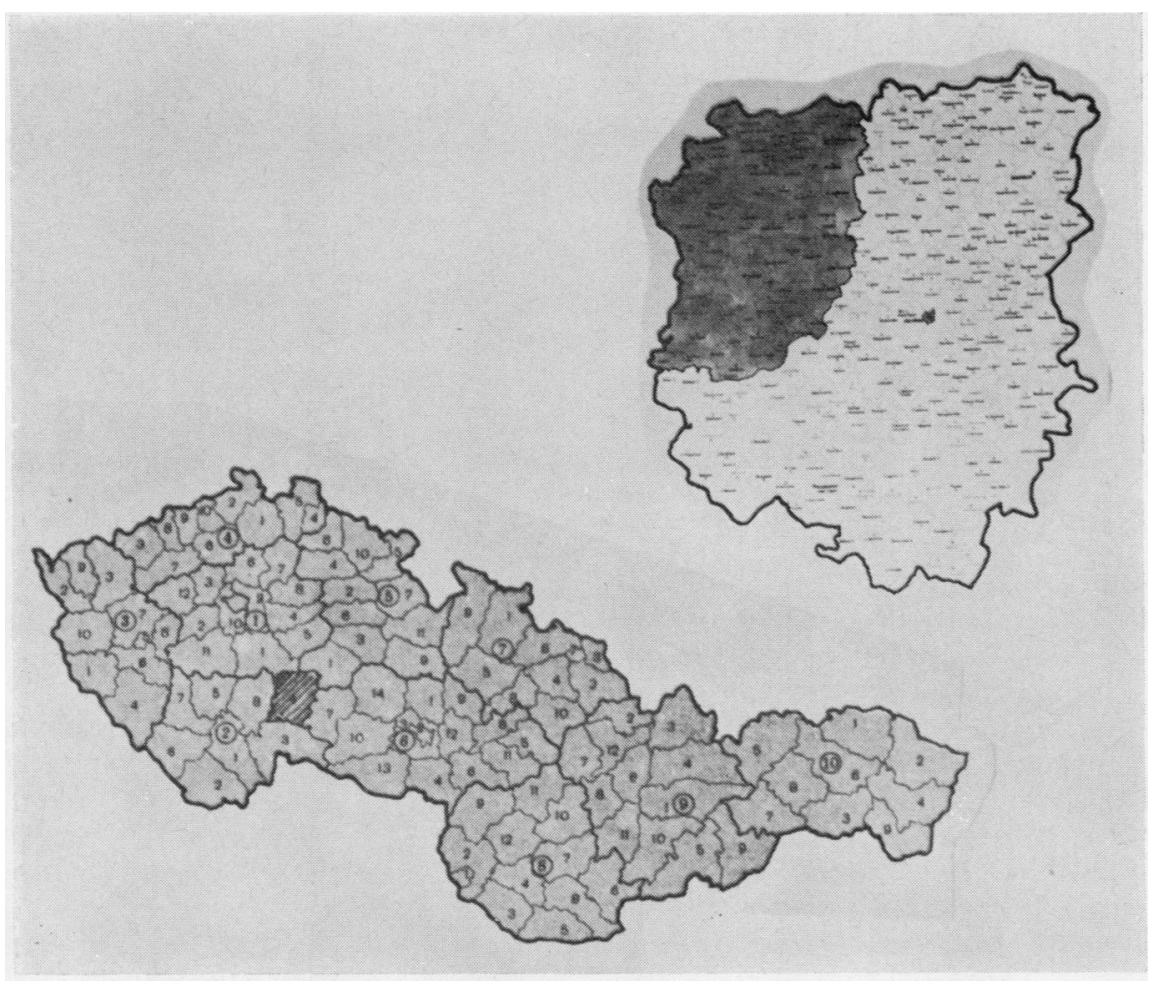

FIG. 1. Map of Czechoslovakia with Pelhřimov district indicated by cross-hatching. Above it is an enlarged view of Pelhrimov district with the study region (shaded area).

eligible for investigation according to lists prepared by the local authorities. Of these, 9,760 (79\%) attended. PP were found in 644 persons

T A B L E I

AGE DISTRIBUTION OF POPULATION, POPULATION DENSITY IN STUDY REGION AND MEAN FOR CZECHOSLOVAKIA IN 1965

\begin{tabular}{l|c|c}
\hline Age Groups & Study Region & Czechoslovakia \\
\hline $0-14$ & $24 \%$ & $27 \%$ \\
$15-59$ & $58 \%$ & $59 \%$ \\
60 and over & $18 \%$ & $14 \%$ \\
\hline Total & $100 \%$ & $100 \%$ \\
Population & 48 & 110 \\
\hline
\end{tabular}

T A B L E I I

PERCENTAGE DISTRIBUTION OF GAINFULLY EMPLOYED INHABITANTS IN REGION UNDER STUDY ACCORDING TO OCCUPATION, 1961

\begin{tabular}{|c|c|c|c|c|}
\hline & Agriculture & Industry & Other & Total \\
\hline $\begin{array}{l}\text { Czechoslovakia .. } \\
\text { Pelhłimov district } \\
\text { Study region }\end{array}$ & $\begin{array}{l}22 \cdot 7 \\
41 \cdot 7 \\
51 \cdot 2\end{array}$ & $\begin{array}{l}39 \cdot 0 \\
32 \cdot 5 \\
25 \cdot 2\end{array}$ & $\begin{array}{l}38 \cdot 3 \\
25 \cdot 8 \\
23 \cdot 6\end{array}$ & $\begin{array}{l}100 \\
100 \\
100\end{array}$ \\
\hline
\end{tabular}

(6.6\%) submitted to investigation. The PP incidence for the entire population (including defaulters) was calculated (Fig. 2).

We believe that photofluorography is the best method for studying the incidence of PP in the population, although we recognize, as did Hourihane, Lessof, and Richardson (1966), that this lesion is visible on chest radiographs in only a proportion of cases detected at necropsy. Meurman (1966) concluded that PP may not show up on chest radiographs even when calcium salts can be demonstrated histologically. For radiological demonstration, a certain intensity of calcium salt deposition is necessary, and the appropriate portion of pleura must be well visualized. In doubtful cases fluoroscopy was used, and supplemented, if necessary, by films taken in inspiration and expiration. PP were not diagnosed when doubtful lesions were seen in the region of costal cartilages, and in all cases with a history of tuberculous empyema, artificial pneumothorax therapy and chest trauma. Small lesions on the costal and diaphragmatic pleura were not 


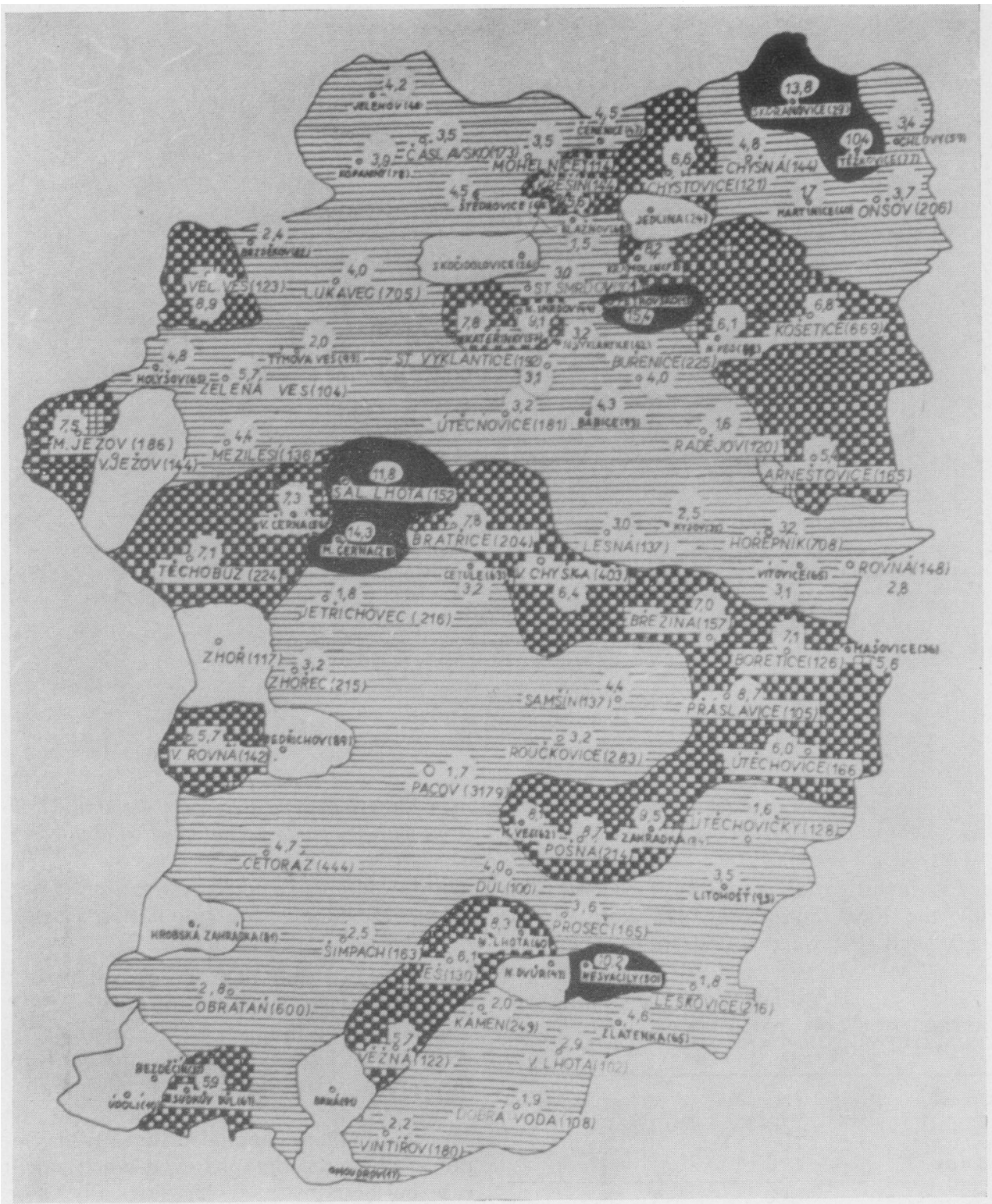

FIG. 2. Incidence of PP in individual communities of study region as percentage of respective population. Without cross-hatching, no PP; horizontal hatching, from $1-5 \%$; chequered, from $5-10 \%$; black, above $10 \%$ incidence.

included as we were unsure that they were PP, although subsequently necropsy observations have confirmed that they were. We have included lesions in persons with a medical history of 'pleural effusion' who had the typical pattern of PP.
On the costal pleura, PP are map-like structures $\frac{0}{0}$ of bizarre shape with irregular, but sharply de- $-\frac{\vec{D}}{}$ fined borders. Less commonly, they may be $\frac{?}{\mathbb{P}}$ structures resembling beads on a string, in a spherical or angular form. In the lateral parts of the chest. these structures tend to maintain the 


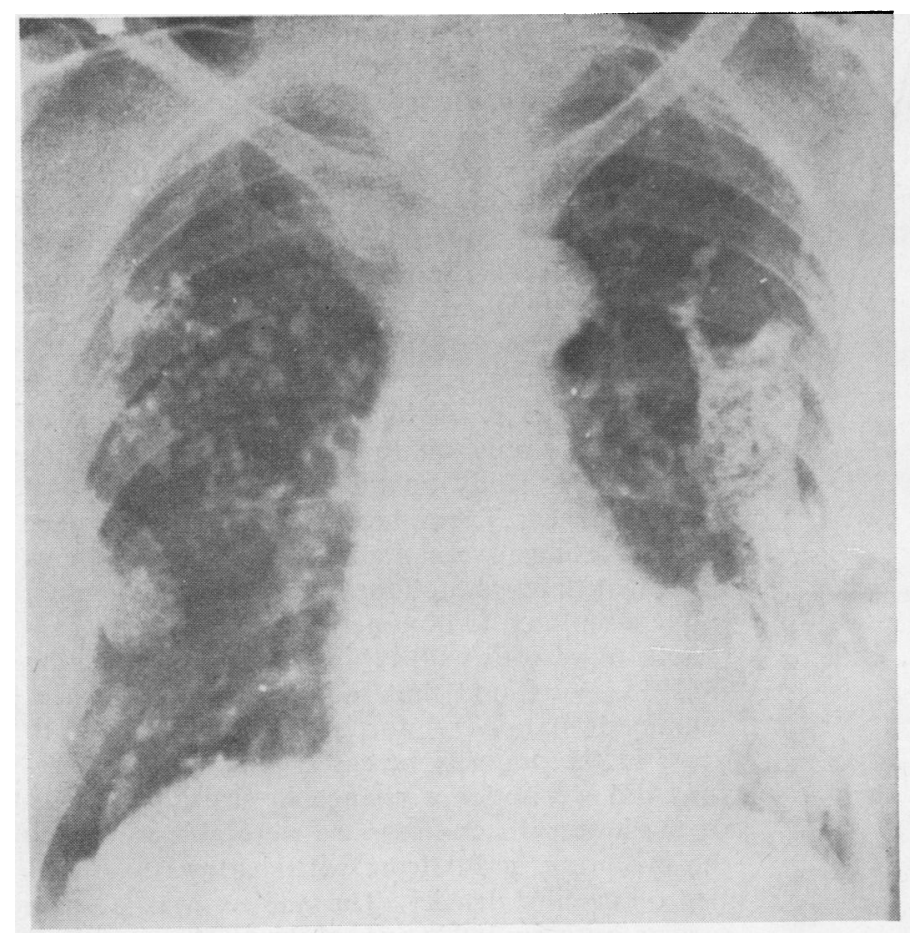

FIG. 3. Woman aged 60 years. Extensive $P P$ on costal, diaphragmatic and mediastinal pleura. Died from tuberculous meningitis. No lung lesions found even at necropsy.

FIG. 4. Man aged 76 years. Extensive PP on costal pleura and lesions of domes of the diaphragm. On left, irregular thickening of diaphragm; on right, band bordering diaphragm and above it, parallel calcifications.

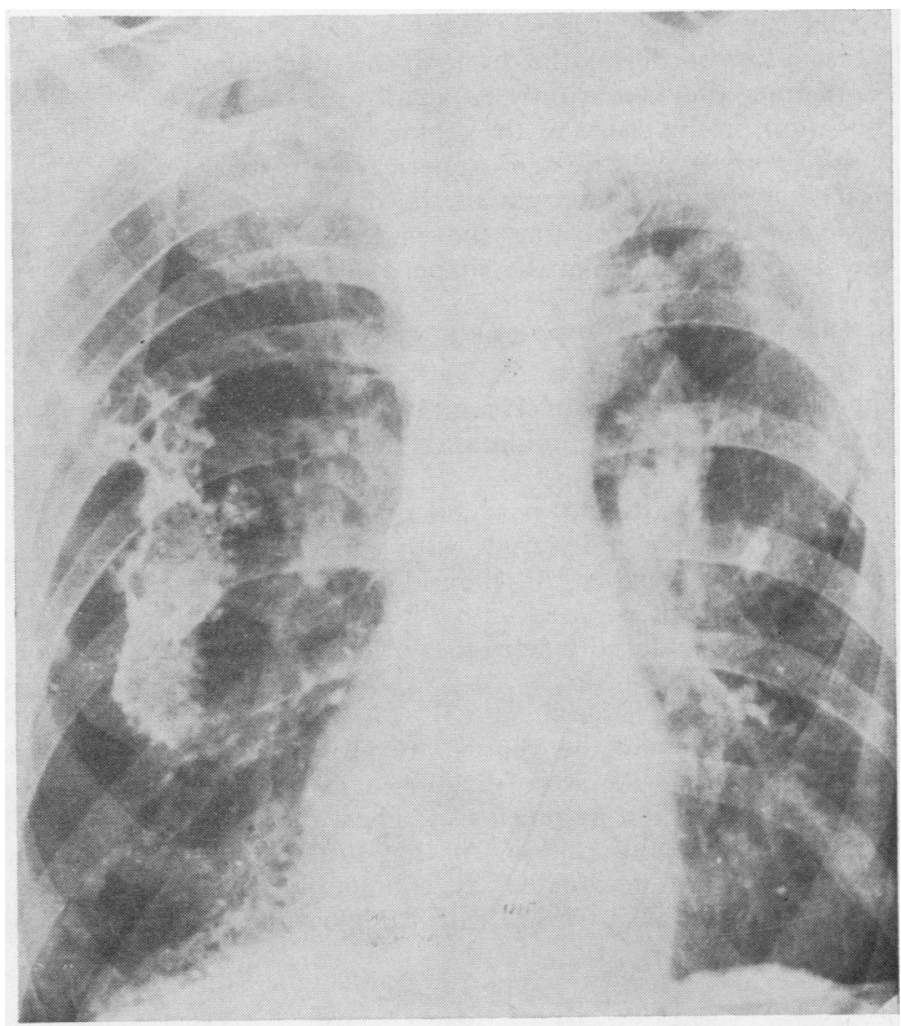




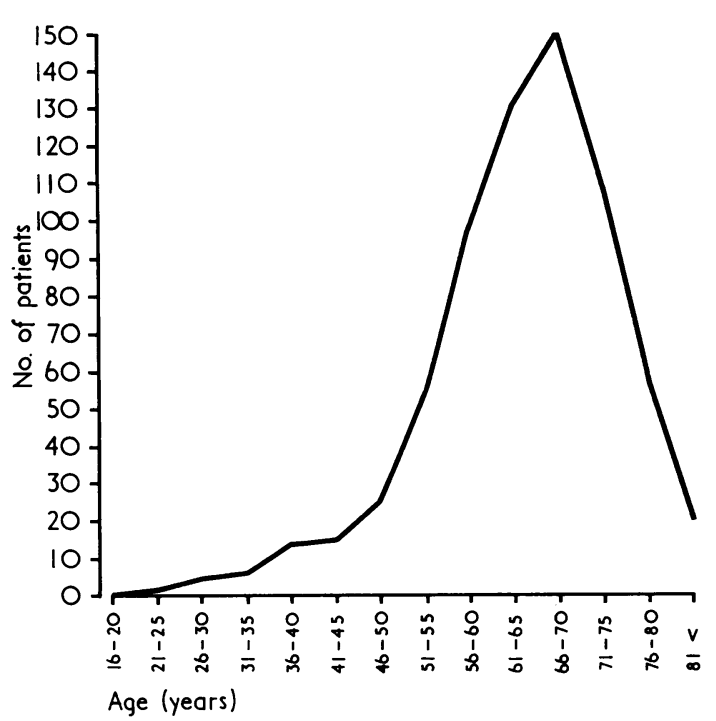

FIG. 5. Age distribution in absolute figures of persons with $P P$ in the region submitted to study.

course of the interspaces. Sometimes they are so large that they obscure the greater part of the lung field, but some are so small that they resemble minute calcifications. PP located on the diaphragm assume the shape of a dense bandlike shadow bordering the dome of the diaphragm. Sometimes they show only as small areas of calcification on the dome of the diaphragm. In a few cases, gross or delicate semi-spherical knobs were noted on the upper margin of the diaphragmatic plaques. Lesions affecting the pericardium and mediastinal pleura take the shape of dense bands (Figs 3 and 4).

The incidence of PP was highest in the age group 66-70 years (Fig. 5). The conclusions are thus similar to those of Hromek (1962), namely that the older the population, the higher the incidence.

There is usually no past history of lung or pleural disease in individuals with PP. However, $9.7 \%$ gave a history of pleural effusion. The general health of persons with PP was good and did not differ materially from that of other persons in the same age-group.

According to Selikoff (1965), PP have been detected only since the year 1940 . However, we have found that PP were diagnosed as early as 1930, when the first apparatus for chest radiology was installed in our region. At that time the appearances were designated as tuberculous. According to Jedlička (1968), all calcifications of unknown aetiology were at that time considered as evidence of previous tuberculosis.

This was exemplified by a woman now aged 81 who in 1932 was diagnosed as having tuberculous 'lung disease' and was granted a disability pension on account of it. In 1948 she successfully appealed to the courts for her pension to be continued. No lesions were visible in the lung fields, but there were typical appearances of PP.

The incidence of PP in other areas of the Pelhřimov district is much lower, ranging between $0.1 \%$ and $0.3 \%$. A high incidence of PP was found by us only on the territory adjoining the region under study on the south, in the area of Cernovice near Tábor health community. Typical pleural lesions were found in $4 \%$ of persons investigated by photofluorography in that region.

We attempted to obtain all previous chest radiographs of persons with PP in this region beginning in 1955. We found that radiological appearances remained stationary for periods exceeding 10 years in the majority of cases. Only in three persons did we notice a change in size and density of the lesion. In one case we were able to follow the evolution of PP from soft shadows to opacities of calcific density. The subject was a male farmer born in 1903, one of whose two brothers also has PP. His wife died in 1967 from tuberculous meningitis, but no tuberculous lung lesions were detected, even at necropsy (Fig. 3). Cattle kept by the patient were repeatedly found to have tuberculosis. In 1957, pulmonary tuberculosis with cavitation was diagnosed in the right upper lung zone, and there were also soft changes bilaterally in the mid and lower zones. Ten years later, bilateral, calcified, dense shadows were seen in the same locality as the soft shadows had been, and the typical pattern of PP was present.

\section{MORBID ANATOMY}

PP are seen frequently at necropsies in the Pelhrimov district. Thus they were found in onefifth of the 161 necropsies carried out on subjects over the age of 15 years in the period March to June 1968. In the area within this district studied specially, almost half of the cases coming to necropsy showed PP (Table III). In contrast, $\varphi$ pathologists working in other centres, such as $\mathbb{D}$ Prague, Brno, and Southern Bohemia, have told : us that they may find the condition only a few times a year (Bednár et al., 1963).

Macroscopically the plaques may assume one of two main forms. First, they may appear as flat, map-like areas of pleural thickening. Usually such areas are extensive and have sharply defined 
T A B L E I I I

INCIDENCE OF PLEURAL PLAQUES IN UNSELECTED NECROPSIES IN THE PELHKIMOV DISTRICT

\begin{tabular}{ll|c|c|c|c}
\hline & \multicolumn{2}{|c|}{$\begin{array}{c}\text { Region Studied } \\
\text { Specially }\end{array}$} & \multicolumn{2}{|c}{$\begin{array}{c}\text { Remainder of } \\
\text { Region }\end{array}$} \\
\cline { 3 - 6 } \cline { 5 - 6 } & $\begin{array}{c}\text { Absolute } \\
\text { Figures }\end{array}$ & $\begin{array}{c}\% \text { of } \\
\text { Notal } \\
\text { Necropsies }\end{array}$ & $\begin{array}{c}\text { Absolute } \\
\text { Figures }\end{array}$ & $\begin{array}{c}\% \text { of } \\
\text { Total } \\
\text { Necropsies }\end{array}$ \\
\hline $\begin{array}{c}\text { Total no. of } \\
\text { necropsies }\end{array}$ & $\ldots$ & 38 & 100 & 123 & 100 \\
$\begin{array}{c}\text { Necropsies } \\
\text { showing PP }\end{array}$ & $\cdots$ & 18 & 47.4 & 13 & 10.6 \\
\hline
\end{tabular}

borders. The surface of these plaques may be smooth (Fig. 6) or granular. In the second form the plaques are nodular. The nodules may be solitary or arranged in clusters (Figs 7 and 8). They range in size so that they may be miliary or as large as a pea. Sometimes flat and nodular plaques occur together (Fig. 9).

Such plaques most commonly involve the costal and diaphragmatic areas of pleura, although sometimes the pericardial area is also affected. The mediastinal pleura is rarely involved. The visceral pleura remains normal as a rule. PP are found in the paravertebral zone of the costal

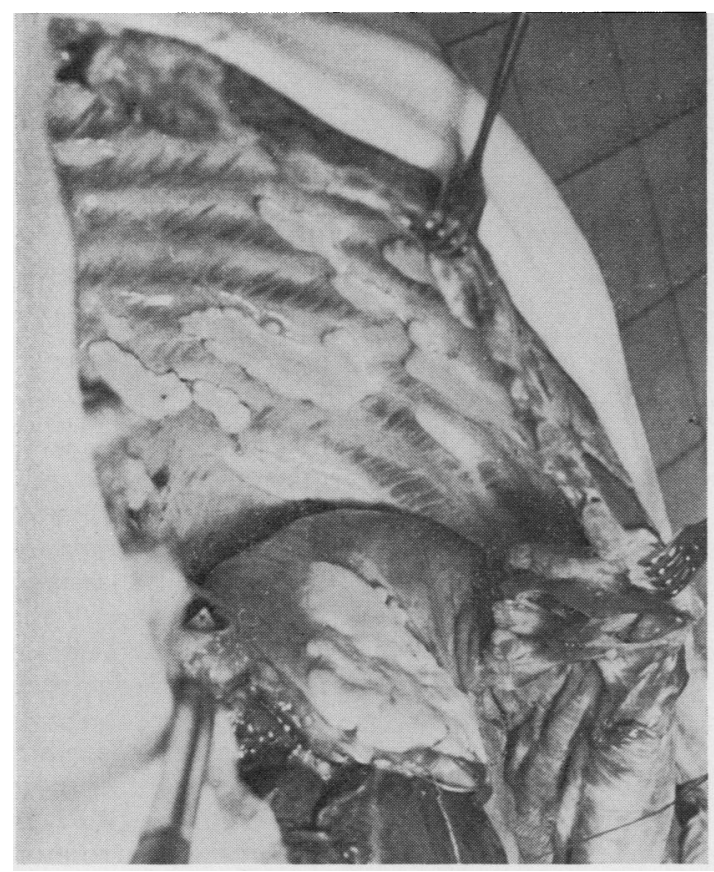

FIG. 6. Flat PP with smooth surface on costal pleura and diaphragm. Human specimen. pleura and they tend to extend along the intercostal spaces. On the diaphragmatic pleura the most pronounced changes occur close to the central tendon.

The plaques vary considerably in thickness, which in some areas may reach as much as $7 \mathrm{~mm}$. They are white in colour and tend to have a lustre reminiscent of mother-of-pearl. They are usually pliable, but frequently they contain deposits of calcium salts when they become brittle. Sometimes individual plaques are connected by bridges of fibrous tissue which are probably vascular in origin (Fig. 10).

Histological examination was made of some of the plaques with adjacent normal-looking pleura which had been fixed in $10 \%$ formaldehyde. Sections were stained with eosin, a combined elasticvan Gieson stain and a trichrome stain. The histological appearances were uniform and showed the plaques to consist of hyaline fibrous tissue with thin-walled blood vessels running between the lamellae of collagen (Fig. 11). At the junction of the plaque and the surrounding normal pleura there was not infrequently a focal chronic inflammatory exudate (Fig. 12). A histological section of the bridge illustrated in Fig. 10 reveals a well-preserved lumen lined by endothelium. The wall of this tube, presumably vascular in origin, is comprised of hyaline fibrous tissue showing a chronic inflammatory reaction.

Dystrophic calcification was common in these plaques of hyalinized collagenous tissue, as might be expected. The flat plaques showed extensive layers of calcification. The nodules showed central foci of calcium salts (Fig. 13) and there was a tendency for this central calcification to extend peripherally, involving successive lamellae of fibrous tissue.

Our morbid anatomical studies have not shed light on the aetiology of this condition. In our opinion, the high incidence of PP in our district of Czechoslovakia supports the concept that they are endemic and are produced by some as yet unknown noxious agent. We subjected 10 specimens to bacteriological investigation and found no tubercle bacilli. No deposits of silica were found in the plaques. We think it unlikely that the plaques are related to the inhalation of asbestos fibres as there has not been a single case of pulmonary asbestosis or mesothelioma in our area for the past eight years. Most of the subjects studied had worked as farmers. No history of contact with asbestos dust could be elicited.

The PP were always incidental findings at necropsy. They never had any relevance to either 


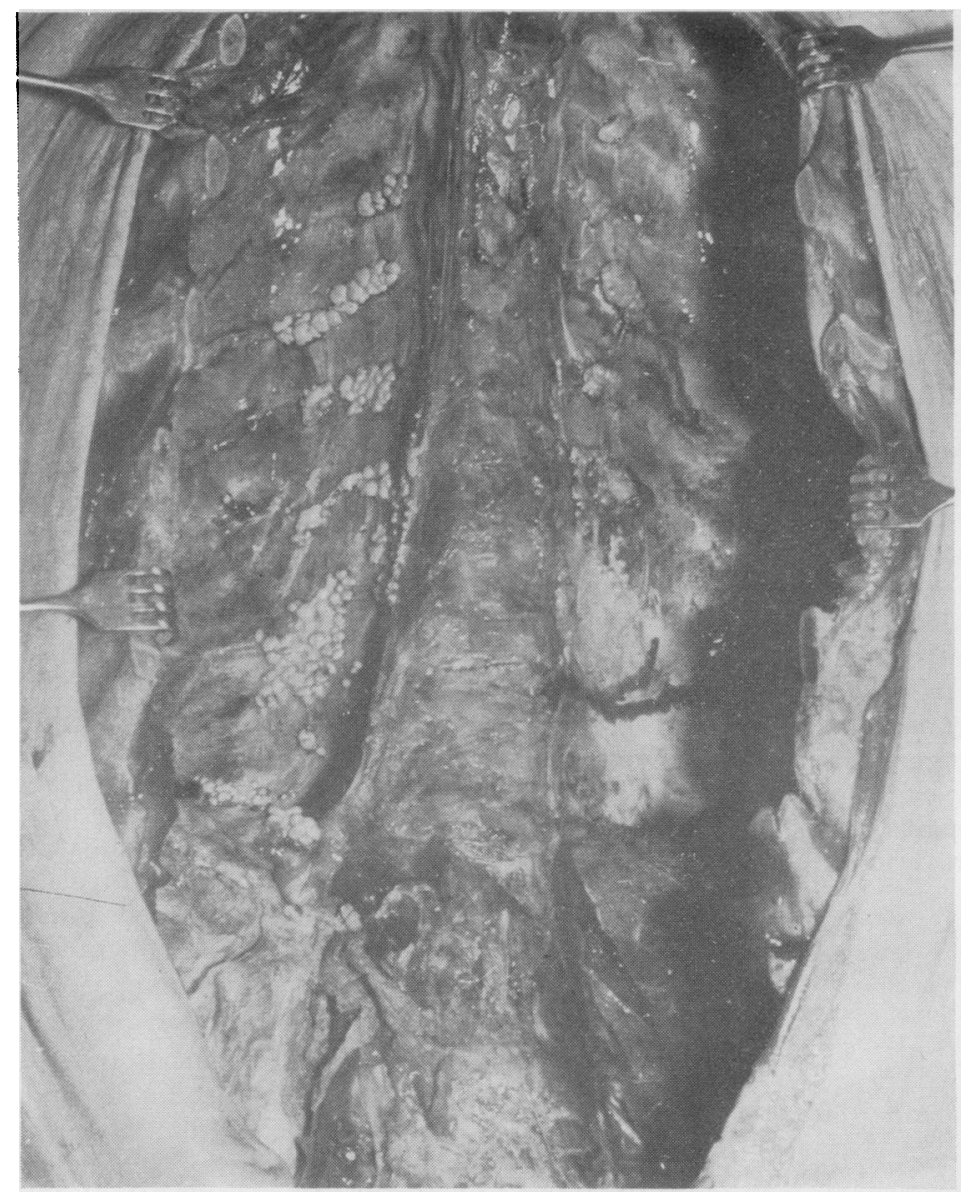

FIG. 7. Beady (nodular) type of PP in man on costal and diaphragmatic pleura. Individual beads vary in size; transformation into mixed type in some places.

the immediate cause of death or the major disease process present. The closest association of the plaque was to the age of the affected subject. PP were commonest in patients in their seventh or eighth decade.

\section{RESULTS OF SURVEY BY QUESTIONNAIRE}

In studying the records of 704 persons in the region with PP, it was found that in 74 families at least two members had PP simultaneously. We concluded from this that the familial incidence amounts to at least $20 \%$. Questionnaires were sent to all the 704 persons in the files asking them to complete queries on parents, husband or wife, siblings and children over the age of 40 years. Altogether 356 questionnaires were returned with $N$ full or partial information and 37 questionnaires were returned blank, the recipient having apparently died. The 300 questionnaires with the most complete data were analysed. The familial incidence as compiled from one questionnaire is indicated in Table IV.

Similar findings were observed in other families, with the majority of siblings coming from the same house affected. The high incidence of PP in siblings indicates that the noxious agent responsible was active mainly during early life and only in some families. In villages with a high inci- 0 dence we encountered some families with 
T A B L E I V

INCIDENCE OF PP IN FAMILY $Z$

\begin{tabular}{l|ll|l}
\hline Parents & Father & 1878 & PP \\
& Mother & 1881 & NA \\
\hline Siblings & M & 1908 & PP \\
& F & 1911 & PP \\
& F & 1912 & NA \\
& M & 1914 & No PP \\
& F & 1916 & PP \\
& F & 1916 & NA \\
& & 1922 & NA \\
\hline
\end{tabular}

NA $=$ films not available

numerous PP and other families without PP. Two farmhouses where persons with PP came from changed ownership. Both the first and second families in them have PP.

Processing of available photofluorograms from members of one family produced the figures set out below (Table V).

In families with two generations suffering from $\mathbf{P P}$, and in which both parents were still alive,

T A B LE V

INCIDENCE OF PP IN FAMILY MEMBERS

\begin{tabular}{|c|c|c|c|c|c|c|}
\hline & & \multirow[b]{2}{*}{ Total } & \multicolumn{4}{|c|}{ No. of Available Photofluorograms } \\
\hline & & & $\begin{array}{l}\text { No Evidence of } \\
\text { Absolute Fig. }\end{array}$ & $\frac{P P}{\%}$ & $\mid \frac{\text { Evidence of } \mathbf{P}}{\text { Absolute Fig. }}$ & $\frac{P P}{\%}$ \\
\hline $\begin{array}{l}\text { Father ... } \\
\text { Mother . . } \\
\text { Husband } \\
\text { Siblings .. } \\
\text { Children over } \\
40 \text { years }\end{array}$ & $\begin{array}{l}\because \\
\because \\
\cdots \\
. .\end{array}$ & $\begin{array}{r}10 \\
12 \\
127 \\
168 \\
58\end{array}$ & $\begin{array}{r}4 \\
6 \\
59 \\
89 \\
49\end{array}$ & $\begin{array}{l}40 \\
50 \\
47 \\
53 \\
84 \cdot 5\end{array}$ & $\begin{array}{r}6 \\
6 \\
68 \\
79 \\
9\end{array}$ & $\begin{array}{l}60 \\
50 \\
53 \\
47\end{array}$ \\
\hline
\end{tabular}

PP were always found in both parents. Hromek (1962) detected PP almost exclusively in farmers. In our series, $85 \%$ of examinees with PP stated that agriculture was their main occupation. This is a larger proportion than the representation of agricultural workers in the whole population of the region studied (cf. Table II). Out of the $15 \%$ who were engaged in a different non-agricultural occupation, $57 \%$ did seasonal agricultural work. Fifty per cent possessed some large domestic animal ; tuberculosis was found in $14.3 \%$ of these animals. PP were found sporadically in persons who had no connection with agriculture, even in their youth, but contact with tuberculous cattle in the past cannot now be determined accurately.

PRESENCE OR ABSENCE OF ASBESTOS IN STUDY REGION Geological surveys of the region have shown no evidence of asbestos in any form. The nearest asbestos mines are at a distance of $400 \mathrm{~km}$; the nearest factory using asbestos in its products is $100 \mathrm{~km}$. away. We investigated 201 workers in quarries and road maintenance in the region. No case of the asbestosis type of pulmonary fibrosis was encountered; the incidence of PP in these workers was lower than it was in the other inhabitants in the area.

Pleural plaques in Veterinary Pathology Like Meurman (1966) we thought it likely that similar PP occur in animals. Veterinary surgeons

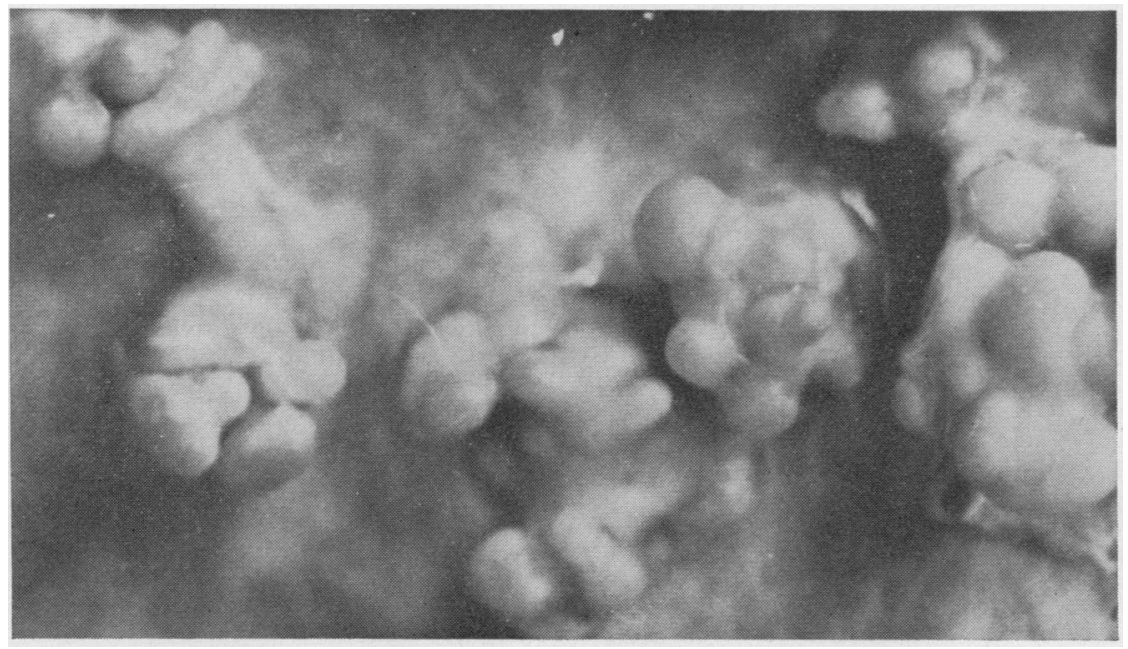

FIG. 8. Nodular type of PP on diaphragm enlarged $\times 2$. The image is very similar to the 'grape cluster pattern' described in bovine nodular pleurisy (tuberculous). 


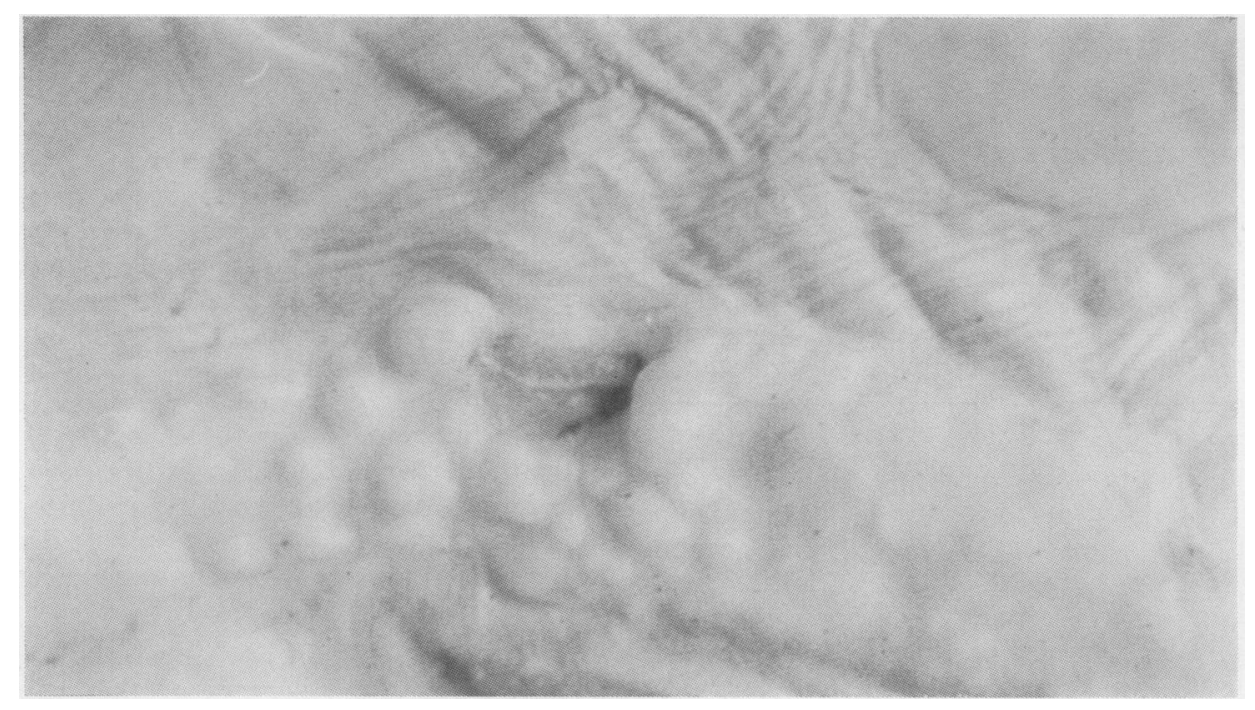

FIG. 9. Mixed type of pleural plaques.

FIG. 10. Bridges (anastomoses) between PP, probably of vascular origin. One variety of these anastomoses. 
pointed out to us the great similarity of our cases to 'pleural beading' in animals, known in Czechoslovakia as 'perlovina' (pearl disease). This condition is brought about by tuberculous involvement of the pleura ; as a rule it is not accompanied by pleural effusions or clinical symptoms. There are many similarities between human PP and this disease of animals. Both conditions are bilateral and involve all areas of the pleura. In neither disease does pleural adhesion and obliteration of the pleural space occur. As in PP in man, dense fibrosis and calcification occur in the 'beading' of cattle (Palec, 1968). Professor M. Zendulka, veterinary surgeon at the Medical

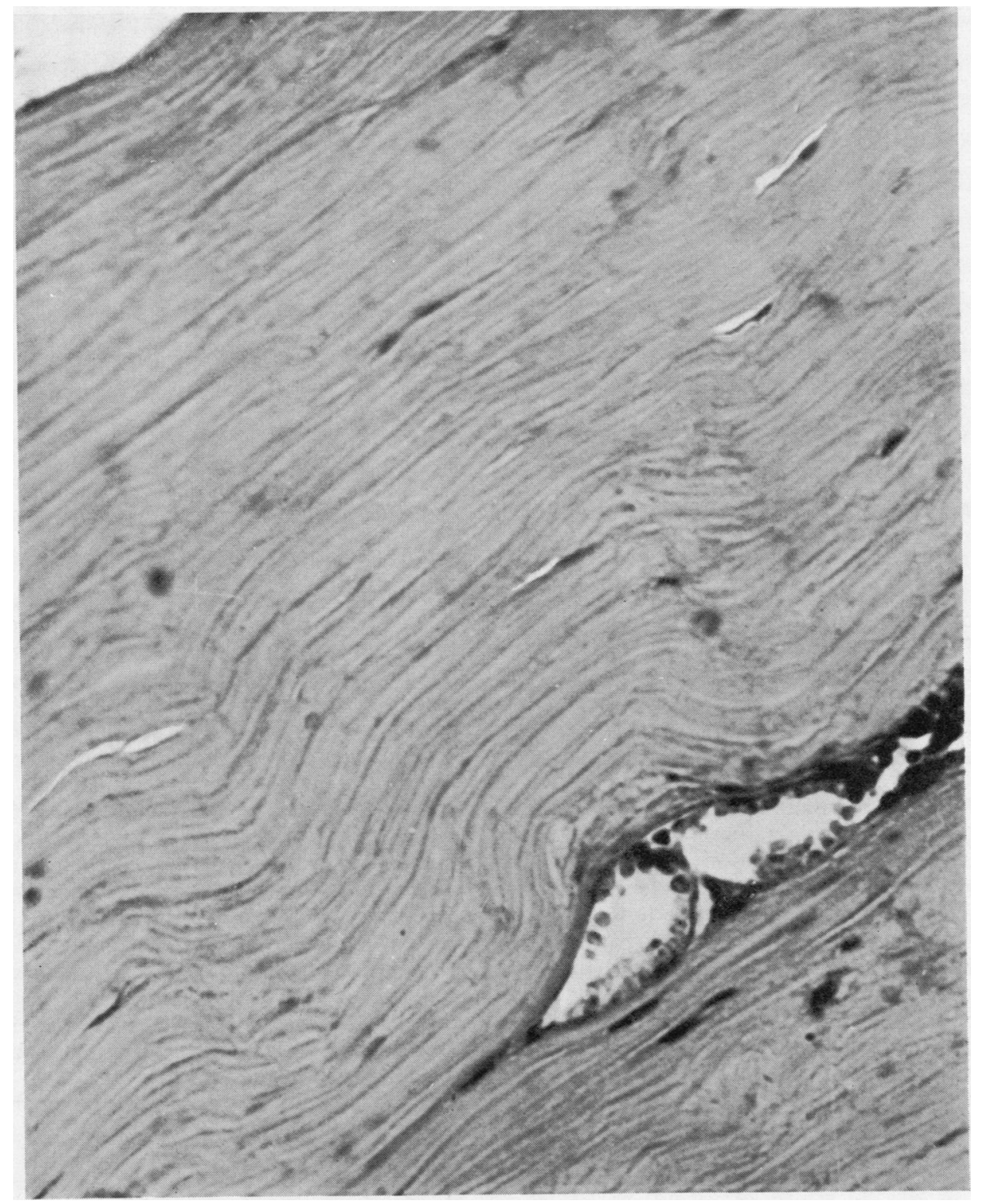

FIG. 11. Fully developed PP. Hyalinization of collagenous connective tissue, little vascularization. Haematoxylin and eosin. $\times 80$. 


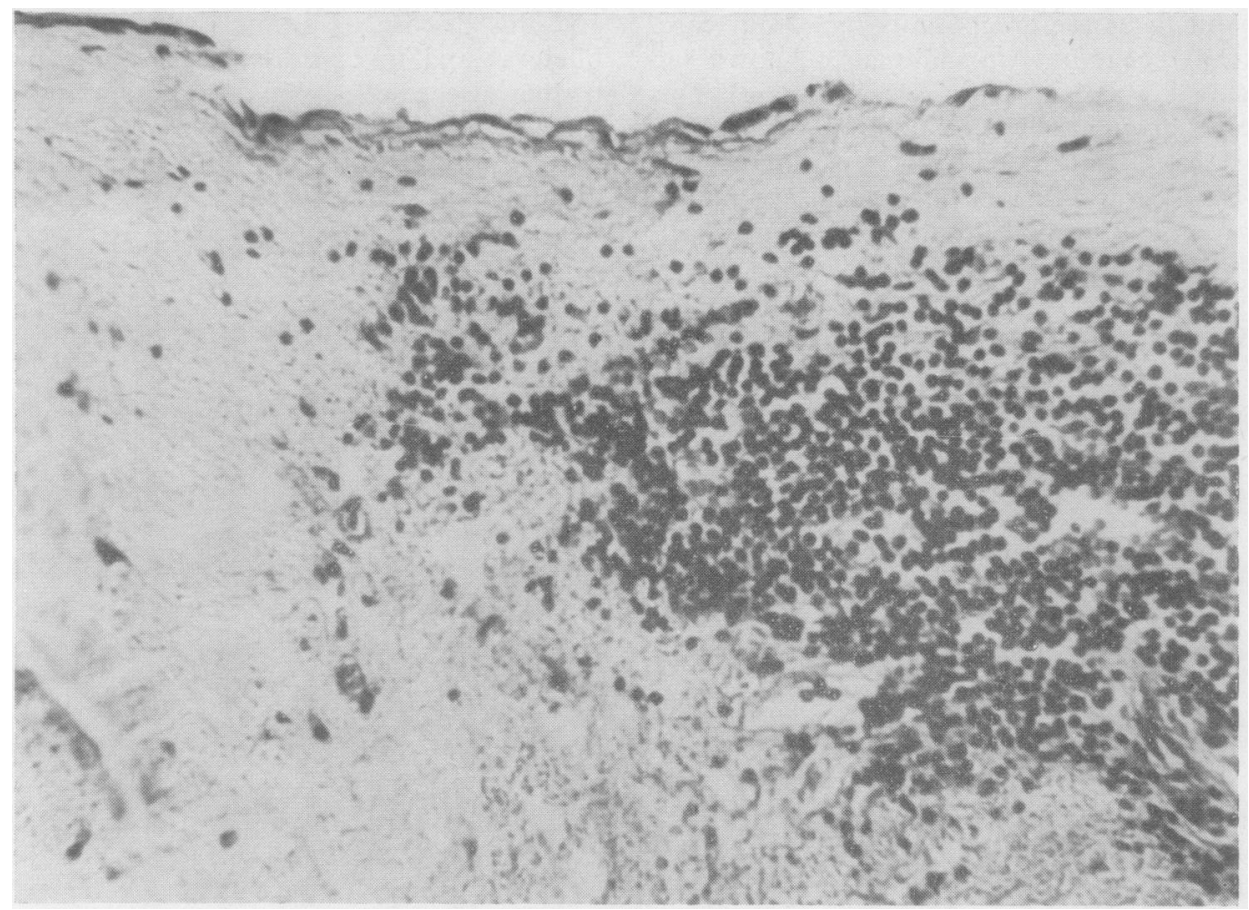

FIG. 12. Marginal zone of PP ('granular' type). An area of minor inflammatory lesions in marginal zone. Haematoxylin and eosin. $\times 190$.

Faculty in Brno, has sent us radiographs which show nodular calcification of the pleura in cattle. Both disorders probably involve the pleural lymphatics. The gross appearances of the two conditions are often similar (compare Figs 7, 8, and 14).

It has proved difficult to determine the incidence of pearl disease in cattle in our district. Bovine tuberculosis has been studied only since 1960 and during this period original relations have been distorted by the collectivization of agriculture in our country. Thus we have been driven to the unsatisfactory method of consulting long-standing residents of our district as to the frequency of pearl disease. Veterinary surgeons and butchers tell us that in the past this condition was very common in the district we have studied. In Czechoslovakia the incidence of bovine tuberculosis was greatest in the period after the first world war, as was also reported in the United States (Francis, 1958).

\section{DISCUSSION}

Several recent papers have suggested that PP are a consequence of exposure to asbestos. Sluis-
Creamer (1965) reported two main radiological features of asbestosis, calcified PP and interstitial fibrosis. According to Selikoff (1965), bilateral PP are, in a majority of cases, pathognomonic for $\frac{0}{0}$ diseases associated with pneumoconiosis and asbestos was by far the most common industrial 3 dust inducing these lesions. He laid stress on the diagnostic significance of unilateral lesions, 옥 because these are rare in the general population and, if they occur, a history of trauma or infection can be elicited as a rule. At present no other $\frac{D}{0}$ occupation is known which can compete with the processing of asbestos in regard to the high inci- $N$ dence of PP. This writer also suggested that the increasing use of asbestos will lead to a rise in the $N$ incidence of these lesions. McVittie (1965) con- $\omega$ sidered bilateral calcified PP to be sufficient evidence for establishing the diagnosis of asbestosis ; and that the perfect symmetry and slow progres- $\mathbb{D}$ sion could hardly be explained other than on the basis of occupation.

Kiviluoto $(1960,1965,1966)$ detected pleural $\stackrel{\circ}{\overparen{D}}$ calcification in persons who had never handled $\stackrel{\varrho}{\Omega}$ asbestos. He suggested that PP are a sequel of $\mathbb{\Phi}$ dust aspiration from a polluted atmosphere and $\overline{0}$ that cases of this kind should be designated as 


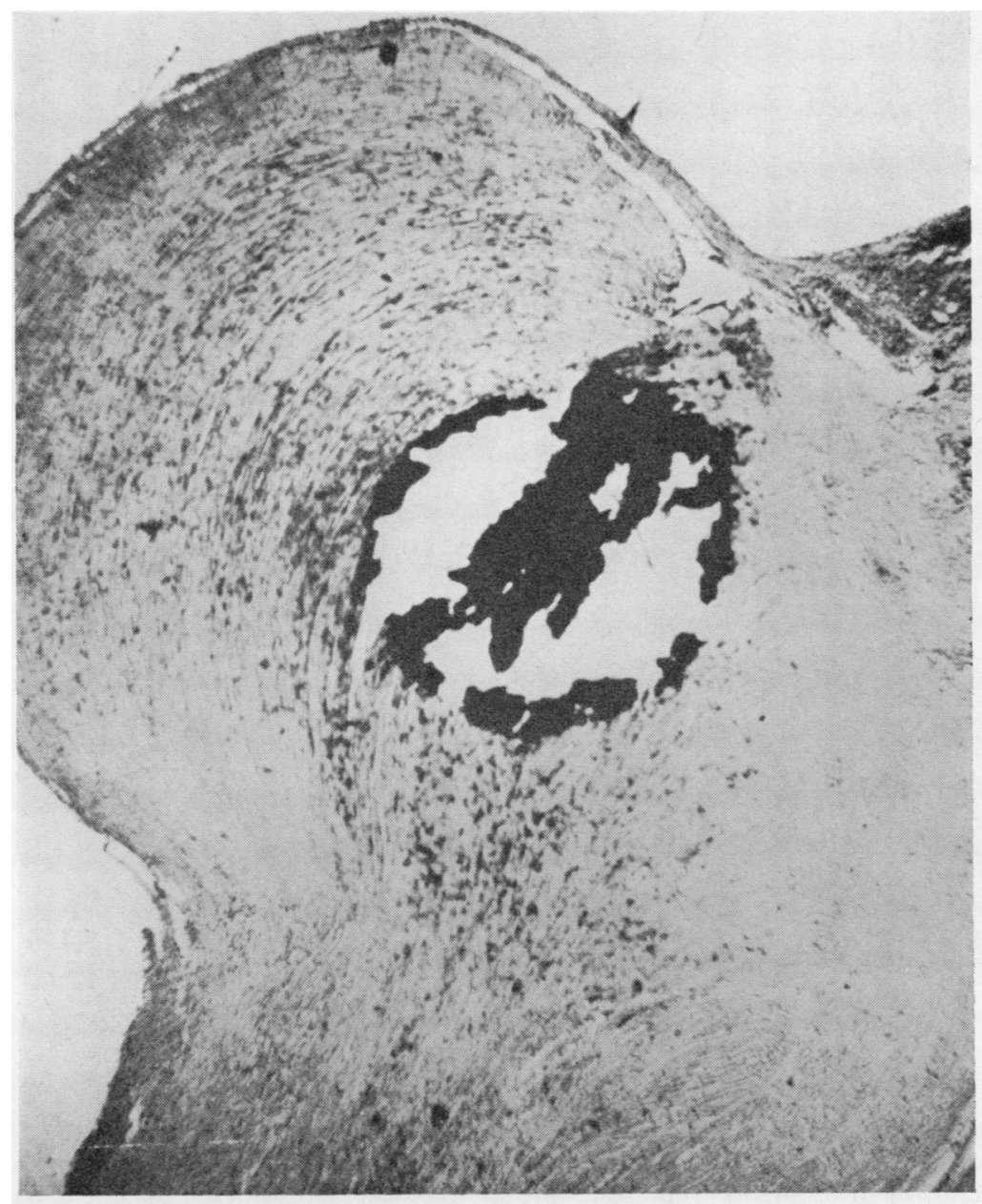

FIG. 13. Calcified 'bead'. Kossa. $\times 65$.

'endemic' or 'pleural' asbestosis. According to this writer's theory, asbestos fibres advancing into the lung periphery penetrate the visceral pleura and by their sharp points traumatize the parietal pleura. They are immobile as far as the visceral pleura is concerned, but this does not apply to the parietal pleura. Lung movement causes lesions to appear in the parietal pleura, inducing minute haemorrhages which are later transformed into fibrous, collagenous tissue and finally calcification. Kiviluoto's theory seems to us unacceptable because it is generally known that asbestos bodies are scattered diffusely in the lungs (Meurman, 1966), whereas PP are localized. Furthermore, Meurman was unable to find in his material any asbestos bodies in the parietal pleura and only rarely in the visceral pleura.

A small group of writers consider PP to represent a disease of obscure aetiology (Hromek, 1962; Tivenius, 1963). Still fewer authors are partisans of the inflammatory theory (GalatiusJensen and Halkier, 1965). Many textbooks on chest diseases fail to mention PP as a separate entity (Bourgeois, 1957).

The incidence in the region studied by us is irregular. The highest incidence of PP in a single village was $15.4 \%$, but none was found in 10 villages. No correlation could be established with chains of hills or river beds. Neither could it be shown that the incidence was higher in small 


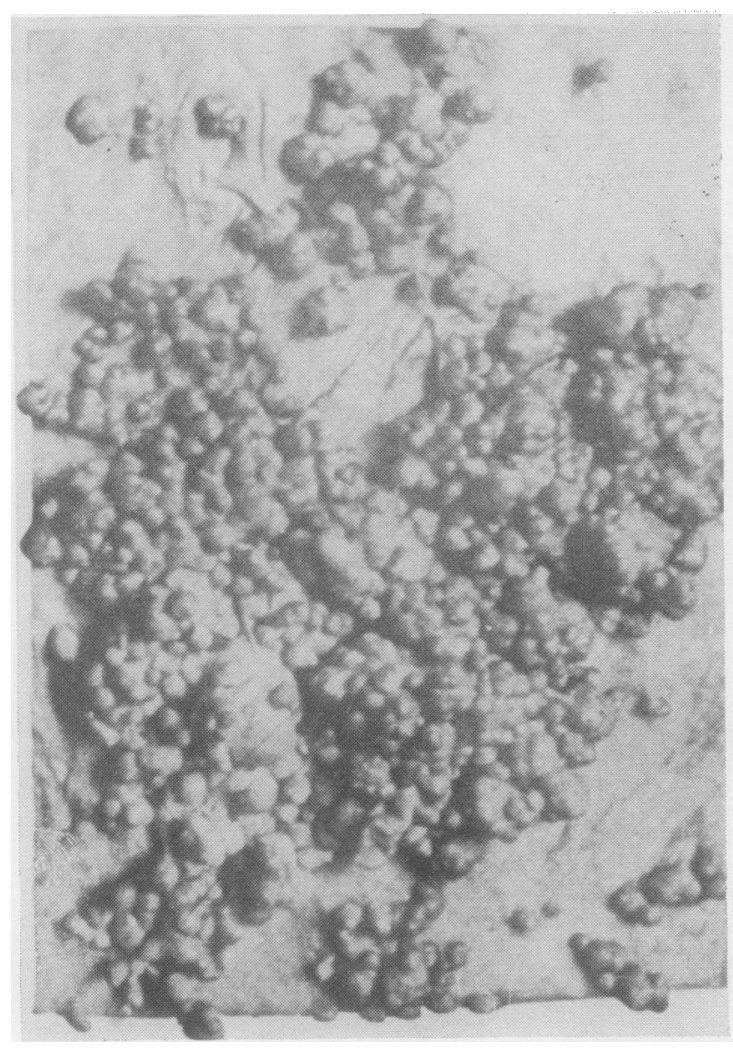

villages, but these have a greater incidence percentage scatter.

PP which consist of hyalinized collagenous tissue with calcium salt deposits represent the final phase of a process whose beginnings are unknown. In most cases the pleura is massively calcified. From a radiological aspect also the pattern is usually that of a final, healed process. Our necropsy material suggested that PP could be due to a variety of noxious agents reaching the pleura. As an example, PP over an infiltrate of lymphatic leukaemia may be cited. Though this PP was only small in size, it had all the required histological characteristics of PP. In our view, it is most probable that the responsible agent is transferred by lymph or blood stream to the location where the PP develops. A useful model of this transfer is 'beady pleurisy', a productive, nodular variety of tuberculous pleurisy in animals. In this disease the noxious agent-the tubercle bacillus-is carried by the lymphohaematogenous route to the pleura and there produces, in the presence of a free interpleural
FIG. 14. Granular pleurisy of cattle from textbook by Hutyra-Marek. space, pathological lesions at the sites where PPo are also found. These lesions are later transformed by connective tissue and calcify.

Asbestos cannot be accepted as an aetiological factor responsible for the origin of PP in ouro series. Asbestos was not found in the soil and $₹$ employees occupationally exposed to dust had 을 no higher incidence of PP. We failed, as did $>$ Meurman (1966), to find in our area interstitial fibrosis of the asbestos type on chest radiographs N or at necropsy. In our district PP incidence in agricultural workers is high. The percentage of $\tilde{O}$ persons engaged in agriculture out of the total $\mathrm{W}^{N}$ working population in the region studied $(51 \%)$ 을 is much lower than the percentage of personso engaged in farming amongst bearers of PP $(85 \%)$.

We confirmed Hromek's view (1962) that the older the inhabitants submitted to survey, the 0 higher the incidence of PP. From the question- $\bar{O}$ naire we concluded that the agent responsible for the origin of PP exerted its action mainly during $\frac{\mathbb{Q}}{\Omega}$ the early life of the persons involved.

We cannot agree with the view that PP were 
discovered only after the year 1940. The oldest data available to us show that PP was detected in one of our cases as early as 1929 and under the then typical designation of PP-namely, pachypleuritis calcarea. Detection of PP in the past was hampered by the lack of facilities for radiography. These methods were gradually introduced in our district from 1930 onward. PP were observed at that time but were interpreted as tuberculous. In Germany, likewise, according to Anspach (1962), this disorder was in the past frequently diagnosed as a post-tuberculous lesion.

There was a striking familial incidence in our series. Familial incidence was also observed sporadically by Anspach (1965) and Kiviluoto (1965), but this was attributed by these writers to asbestos inhalation. We cannot accept their explanation for familial incidence in our material, namely that one family member carried asbestos dust into the house in his clothing. Results from the survey by questionnaire indicate that the noxious agent was probably linked to individual houses in the past. We believe that this might have been an infection from an unknown source with either man or animals as the carrier.

PP might theoretically be due to a variety of factors, and we therefore studied human and veterinary pathology in order to discover the possible agents, including parasites, moulds, viruses, industrial dusts, tuberculosis and many other diseases. Post-tuberculosis pleural lesions appeared to us as the most likely explanation for PP. Currently the view predominates that posttuberculous pleural lesions in humans are a result of effusions which become organized, with the production of extensive adhesions which may undergo calcification, but tuberculous pleural lesions may occur without adhesions. When we demonstrated the gross pattern to specialists in veterinary pathology, their unanimous diagnosis was nodular ('beady') pleurisy, provided the specimen was of animal origin. PP have much in common with the nodular pleurisy of cattle: lesions are usually bilateral, the interpleural space remains free, localization is identical, there is a tendency to transformation into connective tissue and to calcification, the gross appearance is frequently similar and in both disorders the pleural lymphatics are affected.

Necropsy material from some of the cases showed that anastomoses (bridges) between individual plaques possessed the same histological composition as PP themselves. These are, in our view, vessels which have become obliterated and have undergone the same process of fibrosis as
PP (Fig. 10). Likewise, in nodular pleurisy of cattle, hyperplastic lymph vessels have been described which have undergone the same process of fibrotic transformation which is so characteristic of nodular pleurisy itself (Dražan et al., 1962). The histological pattern failed to confirm a tuberculous aetiology. The pattern is one of a terminated process of fibrosis. We failed to find even islets of cells which might indicate a tuberculous aetiology. From the morphological viewpoint PP might, at most, represent post-tuberculous lesions, where tuberculous tissue has been completely substituted by connective tissue with calcifications. By contrast, specimens obtained from nodular pleurisy of cattle, even if caloification has set in, always show islets of tuberculous granulation tissue. Nodular pleurisy in some mammals may assume the pattern of a nonspecific inflammation (Dražan et al., 1962).

We tried to verify the possible tuberculous aetiology by cultivation of PP for the presence of Mycobacterium tuberculosis. Results obtained have been consistently negative.

We also submitted specimens of PP and adjoining lung tissue to examination for the presence of silicon compounds. No silicates were found in the PP and the silicon content of the lung tissue was within normal limits.

As stated earlier, the prevalence of PP in the region studied by us was reported previously by Hromek (1962) and Marsová (1964). We agree with Hromek that this is a disorder chiefly affecting farmers and mostly older people, and that no certain aetiologic factor has yet been established, but we cannot support the view that this disorder involves solely persons over 40 years of age, though it is rare under this age. We confirmed Marsovás finding that PP also occur on the visceral pleura, although this localization was encountered only sporadically in our necropsy material. We do not accept the view that PP in our region could result from asbestos aspiration contained in small amounts in burnt lime used by farmers as fertilizer. This method of exposure could affect only a small minority of the cases. Furthermore, Marsová herself pointed out that in the neighbourhood of Chýnov, where the lime kilns are situated, PP are less common than in the study region.

In the study region there were several instances of PP in combination with active tuberculosis. The majority were cases of cavitary tuberculosis of the lung; less frequently, there was tuberculous empyema. There were two cases of tuberculous meningitis. However, in this region the 
incidence of tuberculosis was not higher than in the rest of the district during recent years. In the territory where PP was not endemic active pulmonary tuberculosis with PP was not observed. We failed to observe a higher incidence of bronchogenic cancer in persons with PP compared with the general population. An important fact was a history of past pleurisy with effusion in $9.7 \%$ of cases. Correlation of the gross appearances at necropsy with the chest radiograph revealed some radiological characteristics not described in the literature, such as irregular thickening ('knobs') of the diaphragm.

The results of our study show that PP are an endemic disorder in our district, mainly found in farmers, with a considerable familial incidence and chiefly affecting persons in later life. Morphologically these lesions reveal fibrotic transformation without evidence of any activity. The aetiology remains obscure, though we do not accept asbestos as an aetiological factor. In our opinion, the view held in the past that these lesions are post-tuberculosis must still be considered as possibly correct. We believe that the causative agent-which remains unknownreaches the pleura via the lympho-haematogenous route.

\section{REFERENCES}

Anspach, M. (1962). Sind Pleuraverkalkungen pathognomisch für eine Asbestose? Int. Arch. Gewerbepath., 19, 108.
(1965). Zur Atiologie von Pleuraverkalkungen. Radiol. diagn (Berl.), 6, 341. Bednár, B., et al. (1963). Pathologická Anatomie, vols. I and II. SZN
Prague.

Bourgeois, P. (1957). Maladies de l'Appareil Respiratoire. Flam marion, Paris.

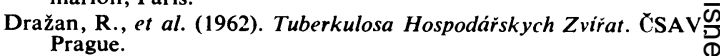

Francis, J. (1958). Tuberculosis in Animals and Man. Cassell, London?

Galatius-Jensen, F., and Halkier, E. (1965). Radiological aspects oहู pleural hyalo-serositis. Brit. J. Radiol., 38, 944.

Hourihane, D. O'B., Lessof, L., and Richardson, P. C. (1966) $\overrightarrow{0}$ Hyaline and calcified pleural plaques as an index of exposure to asbestos. Brit. med. J., 1, 1069.

Hromek, J. (1962). Hromadný výskyt charakteristických pleurálních $\vec{\omega}$ zmên u obyvatelstva západní cásti bývalého Jihlava kraje? (Large-scale incidence of characteristic pleural changes in the inhabitants of the western section of the former Jihlava region. Rozhl. Tuberk., 22, 405 .

Jedlicka, J. (1968). School of Medicine, Charles University Prague Personal communication.

Kiviluoto, R. (1960). Pleural calcification as a roentgenologic sigriv of non-occupational endemic anthrophyllite-asbestosis. Acta radiol. (Stockh.), Suppl. 194.

- (1965). Pleural plaques and asbestos: further observations or endemic and other nonoccupational asbestosis. Ann. N.Y. Acad. Sci., 132, 235.

(1966). Radiological aspects of pleural hyalo-serositis. Brit
J. Radiol., 39, 233.

McVittie, J. C. (1965). Asbestosis in Great Britain. Ann. N.Y. Acad Sci., 132, 128.

Marsová, D. (1964). Beitrag zur Atiologie der Pleuraverkalkungen Z. Tuberk., 121, 329.

Meurman, L. (1966). Asbestos bodies and pleural plaques in Finnish series of autopsy cases. Acta path. microbiol. scand. Suppl. 181

Palec, V. (1968). Personal communication.

Selikoff, I. J. (1965). The occurrence of pleural calcification among asbestos insulation workers. Ann. N.Y. Acad. Sci., 132, 351응

Sluis-Cremer, G. K. (1965). Asbestosis in South Africa. Ann. N.Y@ Acad. Sci., 132, 215.

Tivenius, L. (1963). Benign pleural lesions simulating tumour Thorax, 18, 39. 